\title{
Sparks continue to fly in Taq patent dispute
}

London. Cetus Corporation, the Californiabased biotechnology company, has been accused by the laboratory supply company Promega of presenting the US Patent Office with arguments that were "at best fallacious and at worst deliberately misleading" in defending its claim to a patent on the thermostable enzyme Taq polymerase.

The accusation is based on evidence that Promega is presenting to a federal court in California to back up a challenge to the validity of the patent, which was granted in 1990 (see Nature 372, 714; 1994). The case, including a response from Hoffman-La Roche, which purchased full rights to the patent in 1991 as part of a \$300-million agreement, will be heard in a San Francisco court next week.

It has also emerged that the Cetus/Roche claims on Taq polymerase are being challenged in Australia by another laboratory supply company, New England Biolabs, which sells its own thermostable polymerases VENT and Deep VENT. The main thrust of the challenge is over the breadth of the Australian patent; but a company lawyer said last week that Promega's position "is consistent with the position that we have taken".

Roche is planning to react vigorously in court to the charges which, in an unusual move, Promega has decided to publicize through making supporting documentation available directly on the Internet.

Tom White, vice-president for research and development of Roche Molecular Systems, said on Monday that the company, which normally has a policy of not commenting publicly on on-going litigation, intended to refute each of Promega's charges. "We are fully confident that our Taq patents will be upheld," he said.

The stakes on both sides are high. If Promega loses its challenge, it would seriously weaken its defence against a previous suit filed against it by Roche - also to be heard in court next week - for allegedly infringing a licensing agreement by permitting its (Promega's) Taq polymerase to be used for polymerase chain reaction (PCR) procedures.

The principal issue at stake remains whether the thermostable enzyme extracted from Taq polymerase by scientists working for Cetus is identical to similar enzymes extracted from the same organism - originally discovered in 1969 - which had already been described several times in the literature. If the enzymes were identical, then the existence of so-called 'prior art' would invalidate the Cetus patent.

Three specific instances are referred to by Promega. The first concerns work by a group of Russian scientists (Kaledin et al.) published in Moscow in April 1980, and in English the following year. The second is similar work carried out by a group at the
University of Cincinnati (Chien et al.) and published in 1976. Most recently, Promega has produced a $\mathrm{PhD}$ thesis published two years earlier by David Edgar, later a member of the Cincinnati group.

All describe the extraction of an enzyme with thermostable properties. The first two in particular were raised as possible objections by the US patent official who examined the original patent claim. In reply, Cetus claimed that the enzyme its scientists had 'discovered' was substantially different, both in terms of molecular weight and in the accuracy with which it reproduced nucleotide sequences.

The patent was granted on the basis of these replies. But Promega is now claiming that a series of experiments it has either carried out or commissioned on the Edgar, Chien and Kaledin enzymes indicate that all three are identical to the Cetus enzyme throwing doubt on the validity of Cetus's claims to the contrary.

One test, for example, carried out by Randall Diamond, chief technical officer of the company, using a Western blot technique with antibodies specific for Taq polymerase, showed virtually identical results for the molecular weight of approximately 86,000 to 90,000 daltons of the Edgar and Chien enzymes when compared to the Cetus enzyme (see figure).

Promega claims that other tests challenge claims by Cetus that the polymerase preparations described in the earlier references had been degraded during their purification, and the fidelity of their own enzyme was superior to that of preparations described in these references.

Similarly, Cetus/Roche have placed considerable weight on the results of a preliminary analysis by Jerilyn A. Verhoeven, of the University of Cincinnati, which appeared to show that the Chien enzyme "is actually composed of two identical subunits each

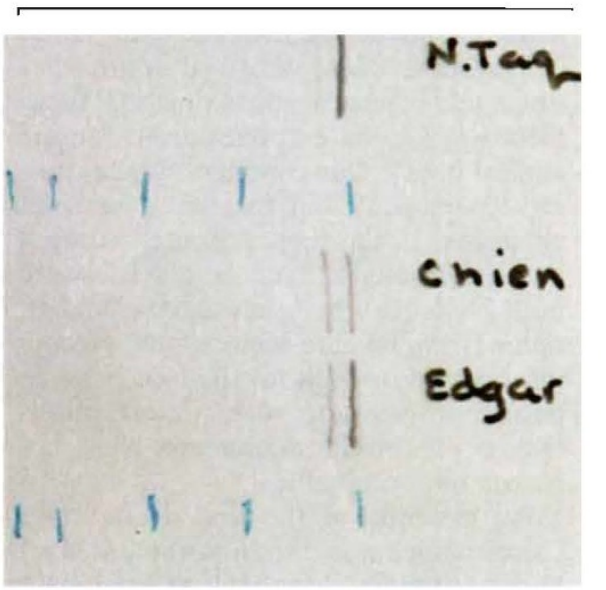

Valid proof? Promega's comparison by Western blotting of the $n$ Taq enzyme with those in two earlier references. having a molecular weight of $35 \mathrm{kd}$ '. It used this argument, for example, to respond to criticisms from both the US Patent office and the European Patent Office (EPO).

But Promega says that subsequent experiments designed to verify this work (whose results were published in a peerreviewed journal) suggest that this conclusion is flawed, as they showed that the $35-\mathrm{kd}$ protein described by Verhoeven in a "preliminary" report "is not a polymerase" and that the polymerase she had in fact purified had a molecular weight of approximately 90,000 daltons.

Promega's conclusions have been endorsed by Arthur Kornberg, professor emeritus of biochemistry at Stanford University - and winner of the Nobel prize for medicine in 1959 for his work leading to the discovery of DNA polymerase.

In a declaration supporting Promega's challenge to the Taq patent, Kornberg says that he has reviewed all the evidence produced by the company to back up its claims. He concludes that the polymerase described by Edgar, Chien and Kaledin "is the same as" the polymerase described in the Cetus patent claim, and that "certain representations" made to the patent examiner concerning these earlier enzymes and their activity "were incorrect".

But Roche promises to contest these conclusions strongly in next week's court case. White said on Monday that the company intends to demonstrate to the court that "there are several key physical and biochemical characteristics that will distinguish our product from those in the prior art".

Roche also argues that the material which Promega has produced as evidence of "prior art" has already been considered - and rejected - by patent examiners in four continents, namely the United States, Europe, Japan and Australia.

Diamond says that his company's decision to issue details of its allegations on the Internet (they can be obtained through anonymous log-in on ftp.promega.com) is based on a desire to challenge Roche's assertions that its defence of the patent is secure. But he admits, "ultimately the issue is going to be decided in the courts".

Indeed, whatever the outcome of next week's hearing, the issue is likely to rumble on (keeping lawyers in business) for several years. On Monday, for example, a spokesman for the EPO, said that an EPO examiner, having previously told Roche that the patent was to be granted (see Nature 372, $212 ; 1994)$, has at the last moment decided to "reconsider" this decision in the light of new evidence presented by a "third party". Roche said it had not been informed of any such decision - and remained confident that the European patent would still be granted.

David Dickson 